\title{
The Intellectual Tussle Between The Sudanese Mahdi And Muslim Scholars
}

\author{
Dr. Abba Idris Adam \\ Department of History,Faculty of Art and Education, Yobe State University,Damaturu.
}

\begin{abstract}
Muslim historians, as the era of general sense of decline and disintegration of Muslim political entities, particularly the Ottoman Caliphate. This was further aggravated by the European scramble on Muslim lands from as far as Southeast Asia, Middle East and Africa. In these lands, Muslims were politically relegated and forced to play secondary roles in their own lands. This, however, reactivated a certain scenario where Muslims yearned for the appearance of the Mahdi (redeemer or savior). Amidst this controversy, Muhammad Ahmad ibn Abdullah (popularly known as the Sudanese Mahdi) proclaimed himself the expected Mahdi and challenged the Muslims to either join his crusade or be destroyed by God. However, his self-acclaimed Mahdiship did not go unchallenged. This paper analyzes the intellectual controversy between the Sudanese Mahdi and the Muslim scholars. The research adopts qualitative and analytical methods in analyzing and interpreting data in this article.
\end{abstract}

Key Words:-Sudanese Mahdi,Muslim Scholars, Controversy, Mahdiyya.

\section{INTRODUCTION}

The $18^{\text {th }}$ century is often viewed as a "dark age" of Islamic history. It was characterized by a general sense of decline of the most important Muslim political entities, particularly the Ottoman Sultanate.Ibrahim, H. A. (2004). And by the 1880s, European scrambled on Africa and established their colonies in every nook and cranny of the continent. At this time, most of the African Muslims were in a state of moral decadence, social degradation, political instability and corruption, and, Sudanwas not an exception.From the beginning of the $19^{\text {th }}$ century, Sudan suffered from social and political turmoil. These include: first, the violence which accompanied the Ottoman conquest of the country, especially the devastation of Shendi Empire in the 1820s has created a strong desire for revenge. Secondly, the alien inequitable taxation system imposed on the people by force and augmented by the illicit demands of the officials at all levels. Thirdly, the steady attempts of the government to suppress the slave trade, which was considered an important source of wealth and the basis of the domestic and agrarian economy of the country. Fourthly, the partiality of the government to the Shaiqiyya tribe and the Khatmiyya sects ignited the jealousy of the other ethnic and religious groups.Holt, P. M. (1970).

At the apex of these factors, one may point finger at the corrupt administration of the Turkish rulers, who were also accused of brutality and injustice, and their religious conviction was seriously contested by a sector of the Sudanese community. Throughout the period of their administration in the Sudan (1821-1885), they took several measures that aroused the opposition of some powerful religious and tribal groups against their administration.However,I want to believe that the underlying factor that triggered the outbreak of the revolution in 1881 was seemingly religious in nature. For the central call of the movement was the restoration and reestablishment of the faith, and to put an end to religious and political injustice and tyranny.

Amidst this chaos, Muhammad Ahmadibn Abdullah proclaimed himself the expected Mahdi and pledged to save Muslims from Turkish oppression and tyranny.O'Fahey, R. S. (1980).As a result, a sizeable number of people accepted his claim as a person chosen by God to support the faith, restore justice and create peaceful, descent and egalitarian society. Consequently, the Mahdi successfully managed to articulate a revolutionary religious ideology and prepared a ground-breaking army to carry out his revolutionary movement. At this juncture, Muslim scholars and intellectuals ridiculed and mocked Muhammad Ahmad and referred to him as al-Mutamahdi (a pretender), and refuted his claim intellectually.This paper discusses and analyzes the controversy between Muhammad Ahmad ibn Abdullah (popularly known as the Sudanese Mahdi) and the Muslim scholars on whether or not he was truly the expect Mahdi (Messiah).

\section{WHO IS MUHAMMAD AHMAD IBN ABDULLAH?}

Muhammad Ahmad ibnAbdallah, popularly known as the Sudanese Mahdi, was born, according to Holt, P. M. (1989),on the $12^{\text {th }}$ August, 1844 in an island called Labab, in the province of Dongola, Northern Sudan. His family claimed lineage to the Ashraf(descendants of the Prophet peace be upon him), and one of his ancestors had been noted for his piety. Muhammad Ahmad's father, Abdullah, was a boat-builder, and when the 
future claimant of the Mahdiyya was a child, the family moved southwards and settled at Karari, about twelve miles north of Khartoum, where there was a supply of suitable timber. Here, Abdullahi died and was buried, leaving a family of four sons and a daughter.His fullgenealogical list as presented by Al-Kurdufani, I. A., (1972), is Muhammad al-Mahdi b. Abdallah, b. Fahl bin Abd al-Waliy b. Abdallah b. Muhammad b. HajjSherif b. Ali b. Ahmad b. Ali b. Hasab al-Nabiy b. Sabr b. Nasr b. Abd al-Karim b. Hussain b. Aun Allah b. Najm alDin b. Uthman b. Musa b. Ahmad b. Abi al-Abbas b. Yusuf b. Uthman b. Yaqub b. Abd al-Qadir b. al-Hassan al-Askari b. Alun b. Abd al-Baqi b. Sakhra b. Yaqub b. al-HassanibnImam AliibnAbiTalib may Allah be pleased with him.

Shibeikah, M. T. (1978), asserted that after committing the holy Qur'an to memory and receiving education on the fundamentals of Islam in the mosque, his soul focused on Sufism and self-contentment. He believed that human souls must be purified and cleansed from the impurities of this world. After moving to the island of Aba, Muhammad Ahmad devoted his life to meditation and worship. The island of Aba, is strategically located at the river way of the White Nile, thus had a vital role in disseminating Muhammad Ahmad's piety and humility. In fact, it was widely rumoured that he sees the unseen and hears beyond the human hearing.Jalal, Y. (1959). According to Cohen, R. A. (2014), the Mahdi soon gained a reputation and the local community's admiration.

In 1876, Muhammad Ahmad started informing his close associates, family members and friends of his presumed divine selection to liberate his people. However, he requested them to conceal the good news until the time for such declaration comes.Shibeikah, M. T. (1978). Consequently, the Mahdist uprising started in 1881, and by 1885 the Mahdist have sacked the Turco-Egyptian administration in the Sudan and established their own Islamic state called al-Dawla al-Mahdiyya (the Mahdist State). However, five months after the fall of Khartoum, the Mahdi died after suffering from high fever on the $22^{\text {nd }}$ June, 1885 and was buried in Omdurman.

\section{MUHAMMAD AHMAD IBN ABUDULLAH AND THE MAHDIYYA}

The notionMahdiyyadoes not have one distinctive colouring in the history of Islam due to some common disagreements among Muslims scholars and intellectuals.However, it is worth noting that this article is not directly concerned with the ideological basis of the Mahdiyyain Islam, which is any how controversial and divisible, but one or two definitions of the term is seemingly important to understand the subject matter. Thus, Mahdiyya,according to Ibrahim, H. A. (2004), is the belief in an "expected deliverer" or a "superhuman savior" who will come from the unseentowards the end of the world to fill it with justice after it had been permeated by injustice and tyranny. The term "Mahdiyya", is an Arabic word which is derived from the root "Hada" meaning to guide, and the "Mahdi" is accordingly the divinely or rightly guided-one.

However, according to IbnKhaldun (2010), The expected Mahdi will be from the people of the house (Ahl al-Bayt), he will be called the Mahdi, he will support the faith and restore the unity of Islam, and, most importantly, his manifestation will be one of the signs of the Hour (Ashrat al-Sa'ah), the eschatological events preceding Doomsday. In other words, the Mahdi is to appear in the world when the planet is filled with injustice and inequity. According to many traditions, chaos will eventually reign on earth and it will be filled with anarchy. This state of disarray is to precede the end of the world; hence, the Mahdi will appear to restore order to the planet through the rejuvenation of faith and religious teachings.Jason I. (2014).

Having this in mind, Muhammad Ahmad claimed that the title of the Mahdi was bestowed upon him by God to revive religion and that all the obstacles blocking his way to attain the said objective would be cleared, even if this happened to be the Ottoman caliphate.AbuSalim, M. I.(1996).

In a famous Manshur (proclamation), proclaiming himself the expected Mahdi and calling people for compulsory migration to him as directed by the Prophet himself, the Mahdi said: "From the servant of his God Muhammad al-Mahdiibn al-SayyidAbd Allah. I have written and informed all the believers and beloved ones of the directives of the Prophet and warned them of the impending dooms and calamities to which no one will be safe until he joins us as directed by the Prophet S.A.W. himself. We have been shown a place where our religion will be safeguarded and the success of this world and that of the hereafter will be achieved...."Shibeikah, M. T. (1978).Contrary to other Mahdist movements, Muhammad Ahmad had seldom focused on the content of the Qur'an or Hadith to prove his Mahdiship. Rather, he predominantly supported his claim with either vision or presumed "Ilm al-Ghaib" (knowledge of the unseen), which does not entertain questions but requires total submission even when it goes against human reason. This was a powerful tool that was smartly used by the Mahdi to have total control over his followers, and to remove any doubt that they may have in their hearts, particularly so as this knowledge of the unseen was assertively given to him by God in the presence of the Prophet S.A.W. And sometimes his supporters advocated his Mahdiship through miracles they claimed to have manifested in his person. Muhammad M. M. (1987). 


\section{THE INTELLECTUAL TUSSLE}

The most heated intellectual debate between Muhammad Ahmad and the Ulama in the Sudan was on the crux of his movement, the Mahdiyya. However, it is very important to highlight here that none of these Ulama'raised objections or expressed an iota of doubt on the notion of the Mahdiyya itself, but, rather, their criticism was based on the unsuitability and unworthiness of Muhammad Ahmad to assume the role of the Mahdi. In other words, these Ulama' focused on discrediting Muhammad Ahmad's claim on the ground of his utter failure to fulfill the requirements of the Mahdi as clearly spelt out in the Hadith, but they never denied the notion itself. So, the points of contention been the Mahdi and these scholars were centered on the core of his movement, the claim of the Mahdiyya.

\subsection{THE ANTAGONISTS}

Since the onset of his movement, Muhammad Ahmad was openly challenged and sometimes ridiculed by many Muslim scholars, accusing him of falsifying truth and bending facts to support his purported and selfacclaimed Mahdiship. They emphasized that his claim to be the expected Mahdi did not comply with the prophecies outlined in the books of al-Sunan, such as Sunan AbuDawud, Tirmidhi and Musnad Imam Ahmad. In particular, they referred to the prophesied physical characteristics of the Mahdi, place of his birth and genealogy, where they insisted that the Mahdi must be born in Medina from the descent of the Prophet, peace be upon him, through his daughter Fatima. And most importantly, his appearance did not conform to the time of disorder and troubles mentioned in the Hadith, which will coincide with the end of the Time when the whole world would be permeated with injustice, oppression and tyranny.

These Ulama', who were mostly Sunni oriented and graduated from al-Azhar, dismissed Muhammad Ahmad's self-acclaimed Mahdiship in several messages and letters by referring to him as al-Mutamahdi (someone who falsely claimed the Mahdiship) and occasionally a glory seeker who hid under the banner of the Mahdiyya to achieve his personal and selfish interest. These messages and letters of criticism were widely circulated by the Turco-Egyptian administration within and outside the Sudan. Prominent among these Ulama' were Ahmad al-Azhari (1810-1882), the Grand Qadi of the Sudan, and the MuftiShakir al-Ghazi.

In a long letter addressed to Muhammad Ahmad ibn Abdullah in particular and to the Muslim community at large, titled: al-Nasihah al-Amma li Ahl al-Islam an Mukhalafat al-Hukkamwa al-Khuruj an Ta'at al-Imam (General advice to the Muslims on disobedience and disloyalty to the Imam), al-Azhari reminded Muhammad Ahmad of his religious obligation to obey the legitimate authority in the land, and warned him against organizing a revolt. All in all, al-Azhari enumerated some ten (10) reasons that ascertain, in his view, the fallacy of his claim. According to Shoucair, N. (1967), these are: Firstly, the expected Mahdi's birth will take place in Medina and not in Dongola. Secondly, the Mahdi will come from the Ahl al-Bayt (People of the House). Thirdly, prior to the Mahdi's manifestation, an obvious eclipse of the moon and the sun will be recorded in the month of Ramadan. Fourthly, the Mahdi will appear towards the end of the Time from the mountains of Masa in Morocco with white and yellow undefeated flags of victory, on them was the name of Allah boldly written. Fifthly, the process of identifying the Mahdi as mentioned in the Hadith was that the Muslim Ummah will be thrown into chaos after the death of the Khalifa, and that someone will take shelter in the Ka'abahbetweenRukun and Maqam in Mecca. Sixthly, the Mahdi will be guided and rehabilitated by Allah overnight. Seventhly, prior to the appearance of the Mahdi, injustice will be rampant, forces of darkness will take over the affairs of the Ummah, corruption and tyranny will become the order of the day. Eighthly, that Allah S.W.T. will assign an Angel to the Mahdi to inform people that he is the expectedKhalifa(Caliph). Ninthly, during the Mahdi's reign, wealth will be abundant and taxes will be abolished. In other words, the economic well-being of the people will be guaranteed. Finally, the Mahdi will reign for seven diligent and prosperous years. He will fill the world with justice after being permeated with injustice. Jesus will descend from the heaven and together they will both kill the Dajjal (anti-Christ). All these, according to Azhari, did not materialize in the case of Muhammad Ahmad.

In the same vein, another scholar stepped in to also refute, on religious ground, the authenticity and genuineness of Muhammad Ahmad's assertion of the Mahdiyya. MuftiShakir, in his message titled: ButlanDa'awat Muhammad al-Mahdi (The annulment of Muhammad Ahmad's claim), he accused Muhammad Ahmad of being overshadowed by the Sufi false concept of al-Kashf (mystical unveiling) to lead the people astray. Moreover, MuftiShakir reviewed the authenticity of most the of Ahadith on the Mahdiyya, asserting that while some scholars accepted them and maintained that the Mahdi will appear towards the end of the Time, others openly questioned, and, to some extent, doubted them. Shoucair, N. (1967). In his message, MuftiShakir, concluded that Muhammad Ahmad was not the expected Mahdi for his utter failure to meet the requirements of the true Mahdi as mentioned in the Islamic sources and enumerated by al-Ghazali, namely his physical characteristics, birth place, time and place of his appearance, and his ministers and supporters. Shoucair, N. (1967)

Similarly, Sheikh al-Amin al-Darir also partook in discrediting Muhammad Ahmad's claim and movement in his letter to the Mahdi titled: Huda al-Mustahdiala Bayan al-Mahdiwa al-Mutamahdi (Guiding the

DOI: 10.9790/0837-2109120914 www.iosrjournals.org $\quad 11 \mid$ Page


guidance seeker on the true and the false Mahdi). He emphasized that Muhammad Ahmad was not, by any means, the expected Mahdi and advised him to abandon his rebellion against the legitimate authority and to seek Allah's forgiveness. Ibrahim, A. A. (1994).It is important to note that the criticism of the above Ulama' against the Mahdi was so extreme that they had not only dismissed his Mahdiship but also disregarded his reform movement as un-Islamic. This, however, invited some stiff response with similar magnitude from the Mahdi's learned disciples.Notwithstanding this extreme criticism and ridicule by the Ulama', Muhammad Ahmad remained resolute and was never distracted by this onslaught from organizing and orchestrating his movement. I wish to state, at this juncture, that I could not find, within my reach, any substantial response or point by point refutation of these challenges from the Mahdi himself, except occasional reference in his Manshurat (proclamations) to what he sarcastically called Ulama' al-Su' (the evil scholars). In one of hisManshurto all the believers, the Mahdi stated that: "The Prophet SAW said to me you were created from the light of my heart, thus, those who are lucky will believe in you, but the glory seekers, whose hearts had been filled with the love of this material world, will not believe in you." He also said: "The Prophet SAW said: whoever refuses to believe in my Mahdiship has disbelieved in Allah and His messenger. He repeated that three times."Shoucair, N. (1967).

\subsection{THE PROTAGONISTS}

The above castigation and condemnation of the Mahdi by the Muslim scholars did not go unattended to, as several Mahdi's supporters responded promptly. Apparently aggrieved by the scholar's ridicule of his master, Al-Hussain al-Zahra, in his rejoinder to these scholars titled:"al-Ayat al-Baiyinatfi Zuhur MahdiAkhir al-ZamanwaGhayat al-Ghayat" (The clear signs on the appearance of the end of Time Mahdi and extreme purposes), explained what he claimed to be essential pre-requisites and qualifications of the Mahdiwhich Muhammad Ahmad did possess in his view.These include moral uprightness, wisdom in saying and deed, similitude of his name with that of the Prophet, the appearance of a star with a tail and his application of the laws of Allah. Al-Zahradid not only asserted that all these qualities have manifested in the person of the Mahdi, but also argued that his Manshurat (letters) had embodied Allah's message to him. With this assertion in mind, one may infer that al-Zahra has subscribed to the claim that the Mahdi had received revelation from Allah. Furthermore, he dismissed the court Ulama' as glory-seekers who had put their pride and dignity in their pockets for the sake of worldly gains from the government officials. Abu Salim, M. I. (1981).

Another Mahdist supporter in this regard was Isma'ilAbd al-Qadir al-Kurdufani, the Mahdist's official chronicler, in his book titled: "Sa'adat al-Mustahdi bi Sirat al-Imam al-Mahdi" (Happiness of the guidance seeker on the biography of the Mahdi). He presented a detailed account of the Mahdi's life, attributes, battles, and his suitability to assume the Mahdiship. Al-Kurdufani enumerated the Ahadith on the notion of the Mahdiyya and maintained that they tallied with the genealogy, physical and moral qualities of Muhammad Ahmad. However, al-Kurdufani did not bother to examine the authenticity of these Ahadith or at least highlight what the scholars of Hadith said about some ambiguities revolving around their validity. But it could be inferred from his argument that he tactically avoided indulging into such critical area due to scholars' conflicting views about them. In his argument to prove Muhammad Ahmad's Mahdiship, he asserted that he was from the people of the House, his father traced his genealogy to Hassan bin Alibin AbiTalib, while his mother's to Hussain bin Ali bin AbiTalib. Al-Kurdufani, I. A. (1972).

In his response to these scholars, al-Kurdufani cited the Mahdi's victory against the well-trained and better-equipped Turco-Egyptian armies and their allies as a sign of divine intervention in the Mahdi's Jihad against the infidels, and then argued that the enemies of the Mahdi were consumed by fire in the battlegrounds such as Shaykan. All in all, al-Kurdufani believed that Muhammad Ahmad had fulfilled all the requirements mentioned in the Ahadith to assume the role of the Mahdi, but avoided to talk about some key attributes of the Mahdi such as praying in the Ka'abah, knowing too well that the Mahdi died without fulfilling them, since the book was authored based on a special request by Khalifa Abdullah after the death of the Mahdi.Al-Kurdufani, I. A. (1972).

Similarly, al-Hassan al-Abbadi had also defended the Mahdi versus the Ulama' in his book titled: alAnwar al-Saniyya al-Mahiya li Zalam al-Munkirinala al-Hadrah al-Mahdiyya (The sublime lights which erase the darkness of the repudiators of the Mahdism), he reiterated the authenticity of Muhammad Ahmad's claim to the Mahdiyya, and the legitimacy of his Jihad against the Turco-Egyptian administration in the Sudan. He, further, warned of dire consequences against anyone who rejects the Mahdi's call to salvation, and called upon people to join his rank to establish a peaceful and egalitarian society. In his words in English rendering: "The Mahdi was sent by Allah to revitalize religion and detach all the impurities inflicted on it through blind imitation. He came to re-establish Islam as the Khalifa (Caliph) of the Prophet, the heir to His knowledge and the expected Mahdi.”Abu Salim, M. I. (1981).

It is interesting to note that al-Abbadi had viewed the Sudanese Mahdiyya not just as a rescue operation to the Muslims of the Sudan but aimed to salvage the entire Muslim world that had then suffered humiliation and subjugation, and the entire humanity at large. He wrote: "the unbelievers have invaded and occupied most

DOI: 10.9790/0837-2109120914 www.iosrjournals.org $\quad 12$ |Page


of the Muslim territories and reversed the wings of the clock in them, dehumanized them, took them captives and imposed taxes on them...... Together with the Mahdi, we will fight the infidels and unbelievers to save ourselves, our posterity and the entire Muslim Ummah from their doom. And after the fight and victory, we will spread justice and truth to the whole world.” Quoted in Abu Salim, M. I. (1981)

Another probable advocate of the Sudanese Mahdiyya was Ahmad al-Auwam, the author of a manuscript titled "Nasihat al-Auwam li al-Khaswa al-Am min IkhwaniAhl al-Imanwa al-Islam" (The advice of Auwam to special and general people among my fellow Muslim faithful). al-Auwam was an Egyptian scholar who was exiled to Sudan for supporting Urabi's uprising against the tyrant Khedive and the British hegemony over Egypt.He supported the right of the Sudanese people to revolt against the Turco-Egyptian rule. Based on his own reading of Al-Auwam's message, Al-Sadiq al-Mahdi (1970), opined that he was a strong advocate of the course of the Sudanese Mahdi, and summarized what he considered to be his strong views in support of the validity of the Mahdist.He said the leadership of the Ottomans is null and void due to their inability to implement the Shari'ah, and that the Khedive's rule in Egypt had lost its legitimacy because it took advantage of the innocent Egyptian people. Moreover, he argued, it is mandatory upon all Muslims to stand up against the Ottoman Caliph Abd al-Hamid II and the Egyptian Khedive Tawfiq because they were not qualified to lead Muslims due to their inability to meet the qualifications of the Imamah, amongst which are to be an upright Muslim and from the lineage of the Prophet (S.A.W.). Additionally, he maintained, the desperate situation of the Muslims requires someone to lead and unite them whether under the banner of the Mahdiyya or not. Therefore he called upon Muslims to support al-Imam al-Mahdi.

However, AbuSalim, M. I. (1998), has a different position on al-Auwam's presumed support to the Mahdiyya. He argued that al-Auwam clearly reserved his position on the Mahdist movement in the Sudan until he personally meets the Mahdi. This was stated in chapter five of the Nasihat, titled: "al-Mahdi peace be upon him", where he wrote: "I found it better to write this chapter aftermeeting the Mahdi in order to be clear of his movement, so that I can write, in details, the history of his appearance in this world and then compare it with what has been reported from the Prophet S.A.W."

With this quotation in mind, it may be difficult to support the views of al-Sadiq al-Mahdi that alAuwam had fully and wholeheartedly endorsed the Mahdi's claim and even called the Muslims to support his movement. Another point to be noted here is that al-Auwam did not meet the Mahdi personally, and that his manuscript "Nasihatal-Auwam" was taken to the Mahdiafter the fall of Khartoum. Hence, there is no evidence that al-Auwam and the Mahdi have seen each other, and even if they did, this should have been after the fall of Khartoum when the manuscript had already been written and even reached the Mahdi himself.

Similarly, among the contemporary Muslim intellectuals, al-Sadiq al-Mahdi, the great-grandson of the Mahdi, maintains that the qualifications mentioned in the Ahadith are on the whole compatible with the personality and achievements of the Sudanese Mahdi, notably humility, moral uprightness, wisdom in words and deeds, lineage and physical appearance. He also performed some other qualifications mentioned in those Ahadith, such as abolishing Madhhab and sects and leading undefeated flags.Al-Mahdi S. (1970). He conserved that his great grandfather's Mahdist movement was basically a religious movement that aimed at uniting Muslims, reviving their religion and calling them to hold on to the Kitab and the Sunnah. The movement filled the gap of the Khilafa(Caliphate) on behalf of the Prophet S.A.W, and aspired to liberate Muslims from the injustice and tyranny of this world based on the saying of the Prophet S.A.W. "this religion started as a stranger and it will end as a stranger, so give glad tidings to the strangers".

Al-Sadiq further maintains that even though there may be allusions to the concept of Mahdism scattered in Muhammad Ahmad al-Mahdi's letters and statements, the crux of his position depicts a different version of the Mahdiyya whose essentials are: firstly, that there is no truth in the eschatological view of Mahdism. Indeed, all attempts to time the appearance of the Mahdi are meaningless. Secondly, that there is no truth about looking for signs in connection with the appearance of the Mahdi. Thirdly, that the religious, political and cultural conditions of the Muslims in the second half of the $19^{\text {th }}$ century called for urgent and radical reform. Fourthly, the re-birth of Islamic community is possible only by the true commitment to the Qur'an and the Sunnah. Fifthly, the Mahdi has been instructed by the Prophet to fulfill this function. Sixthly, the Mahdi was well aware that the Islamic community will outlive his own life, and hence he appointed successors. (Unpublished memorandum of al-Sadiq al-Mahdi quoted in Ibrahim, H. A. 2004).

\section{CONCLUSION}

In conclusion, having presented this bitter debate between the Mahdi and the Ulama'on the notion of the Mahdiyya and the obedience to the constituted authority, one may infer that a clear and sharp ideological difference between the dominant Sufi thought and the emerging Sunni scholars in the Sudan had reached an alarming proportion. The grudges between the two parties had created a serious vacuum that is yet to be filled. This could be seen in the bitter attacks of the Ulama' and their accusation by the Mahdi of intellectual dishonesty for allowing themselves to be misused by the government to discredit his movement. While these scholars spent their time and energy to save people from falling victims into the nets of glory seekers such as the

DOI: 10.9790/0837-2109120914 www.iosrjournals.org $\quad 13 \mid$ Page


Sudanese Mahdi, the Mahdi's protagonists accused them of conniving with the ruling elites to uproot Islam. So, to them, the Sudanese Mahdi had come with a noble mission to raise the banner of reform which these Ulama' had drastically failed to do.

\section{REFERENCE}

[1] Ibrahim, H. A., SayyidAbd al-Rahman al-Mahdi: A Study of Neo-Mahdism in the Sudan 1899-1956, (Boston: Brill, 2004).

[2] Holt, P. M., TheMahdist State in the Sudan 1881-1898: A Study of Its Origins, Development and Overthrow, (Oxford: Clarendon Press, 1970).

[3] O'Fahey, R. S. State and Society in Dar Fuūr, (London: C. Hurst \& Co., 1980).

[4] Holt, P.M. \& Daly, M.W. A History of the Sudan from the Coming of Islam to the Present Day, 4th ed. (London and New York: Longman, 1989).

[5] Al-Kurdufani, I. A., Sa'adat al-Mustahdi bi Sirat al-Imam al-Mahdi, ed. Abu Salim M. I., (Khartoum: alDar al-Sudaniyya Li al-Kutub, Khartoum, 1972).

[6] Shibeika, M. T., al-Sudan wa al-Thaurat al-Mahdiyya min Mauqi'at Aba ilaHisar al-Khartoum, (Khartoum: Dar Jami'at al-Khartoum li al-Nashr, Vol.1, 1978).

[7] Jalal, Y.Al-Thaura al-MahdiyyawaUsul al-Siyasa al-Britaniyya fi al-Sudan, (Cairo: Maktabat al-Nahḍa al-Misriyya, 1959).

[8] Cohen, R. A. (2014), Upheavals in the Middle East: The Theory and Practice of Revolution, (Maryland: Lexington Books, 2014).

[9] IbnKhaldun, Muqaddimah, (al-Qahirah: Dar al-TaufÊqiyyah li al-Turath, 2010).

[10] Jason I., "Nineteenth Century Islamic Mahdism in Iran and the Sudan: A brief analysis of the teachings and influence of The Bab and Muhammad Ahmad (The Sudanese Mahdi)" http://bahailibrary.com/illari_mahdism_iran_sudan.

[11] AbuSalim, M. I., Manshurat al-Imam al-Mahdi, (Beirut: Dar al-Jil, 1996).

[12] Muhammad M. M., al-Muqawamah al-Dakhiliyya li Harakat al-Mahdiyya: 1881-1898, (Beirut: Dar alJil, 1987).

[13] Shoucair, N., JugrafiyyatwaTarikh al-Sudan, (Beirut: DÉr al-ThaqÉfah,1967).

[14] Ibrahim, A. A., al-Sira' Baina al-Mahdiwa al-Ulama' (Cairo: Markaz al-Dirasat al-Sudaniyya, 1994).

[15] AbuSalim, M. I., al-Harakat al-Fikriyya fi al-Mahdiyya, (Beirut: Dar al-Jil, 1981).

[16] Al-Sadiq M., Yas'alunaka an al-Mahdiyya,(Beirut: Dar al-Qadaya, 1975).

[17] AbuSalim, M. I., Nasihat al-Auwamwa al-AlaqaBaina al-Thauratain al-Urabiyyawa al-Mahdiyya,(alKhartoum: Sharikat Dar al-Balad, 1998).

[18] Unpublished memorandum of al-Sadiq al-Mahdi, full text recorded in: Ibrahim, H. A., SayyidAbd alRahman al-Mahdi: A Study of Neo-Mahdism in the Sudan 1899-1956, (Boston: Brill, 2004). 